\title{
Spanish Influenza in the Heart of Europe. A Study of a Significant Sample of the Basque Population
}

Anton Erkoreka

\section{Summary}

This article presents calculations and comparisons of mortality rates for influenza, for diseases of the respiratory system (with the exception of tuberculosis) and for all the causes of death, in 21 locations in the Basque Country (between Spain and France). The data were collected from all the entries in the death registers for the period between May 1918 and April 1919. The Spanish influenza pandemic affected this population sample to a varying extent. Depending on the characteristic of the different locations, the mortality rate varied between 2.2 and $19.7 \%$ o for influenza, and between 7.5 and $25.7 \%$ o for influenza and other diseases of the respiratory system. The mortality rate for the total population studied has been calculated to be $6.8 \%$ o for Spanish influenza and $12.1 \%$ o for influenza and other diseases of the respiratory system.

The first wave of the pandemic (spring 1918) was benign like a seasonal influenza. The second wave (autumn 1918) was extremely virulent owing to the mutation of the virus in Europe during the summer. This article identifies one of the sites, on the border between France and Spain, from which the second wave of the Spanish flu spread.

Keywords: pandemic; Spanish influenza; virus; mutation; pneumology; Basque Country

As its name suggests the Spanish flu (1918-1919) was associated with Spain from the first weeks of its outbreak. The tragic conditions in which the

Dr. Anton Erkoreka, Medikuntza Historiaren Euskal Museoa, Euskal Herriko Unibertsitatea / Universidad del País Vasco, Medikuntza Fakultatea / Facultad de Medicina, E-48940 Leioa (Bizkaia) (a.erkoreka@ehu.es). 
pandemic spread throughout Europe at the end of the First World War, with millions of men in the front line and millions of civilians uprooted from their homes, meant that the mortality rate was either ignored or that the figures for the number of deaths were deliberately underestimated as a result of strict military censorship.

On checking the mortality rates attributed to Spanish flu in different European countries, we find that there is a considerable disparity ${ }^{1}$, which cannot be put down to the antigenic characteristics of the flu virus and its virulence. It can, however, be blamed on the sources of information and the differing working methods employed by researchers and civil servants to calculate them. In our study we have disregarded the official statistics and the excess mortality calculations. We have concerned ourselves with the analysis of a sample of the population in question and with the calculation of mortality rates directly from the information recorded in death registers.

From the data obtained, we have been able to show that the first wave of the epidemic in the spring and summer of 1918 was relatively benign. We have also been able to confirm that it could have spread from the USA as was suggested by Patterson and $\mathrm{Pyle}^{2}$, but that it also could have spread to Europe as a result of epidemic outbreaks such as "pneumonie des annamites" among the troops in the front line and in the rearguard of the battlefields, a theory borne out by our studies of documents housed in the Archive du Service de Santé des Armées (ASSA) that forms part of the Musée du Service de Santé des Armées au Val-de Grâce in Paris ${ }^{3}$.

The data obtained from our study confirm that during the summer of 1918 the flu virus mutated in Europe. The virus became extremely virulent and this led to the outbreak of a severe second wave of the epidemic in the part of Europe which we have researched, namely the borderline region between France and Spain. We discovered that by September the border town of Irun was one of the sites of the most contagious and deadly wave of the epidemic which, in the space of just a few weeks, was responsible for the death of millions. For those affected by the virus, the evolution of the disease was extremely rapid and the symptoms, characterised by massive haemorrhage in the lungs leading to a sudden and painful death by catastrophic asphyxiation.

1 Patterson/Pyle 1991, 14; Johnson/Mueller 2002, 113; Phillips/Killingray 2003.

2 Patterson/Pyle 1991, 6f.

3 Rapport du Médecin chargé du Service Médical du Centre d'Instruction Automobile IndoChinois sur une épidémie survenue fin avril 1918: «Le 30 Avril, 23 Indigènes se présentèrent à la contre-visite se plaignant de symptômes morbides apparus brusquement dans les heures précédentes et qui peuvent se résumer ainsi: fièvre allant de $38^{\circ}$ à $40^{\circ}$, - toux impérieuse, parfois émétisante, - céphalée - rachialgie - courbature générale; quelques-uns présentaient de la congestion de la face des conjonctives ou du pharynx ...» (ASSA, carton 810). 
In October 1918, the pandemic struck simultaneously in places as far away as Bordeaux ${ }^{4}$, Paris $^{5}$, Lyon $^{6}$, Andorra $^{7}$, Barcelona $^{8}$, Alicante ${ }^{9}$ or Madrid $^{10}$. This implies that the virus spread to other parts of Europe at a fearful rate. The fact that it spread so rapidly over the whole continent makes it difficult to believe that it was the result of land and person-to-person transmission exclusively. One has to assume therefore that there were other means of contagion: airborne transmission, birds on their autumnal migratory flights acting as carriers.

The virus responsible for Spanish flu has recently been recreated in laboratories using the pulmonary remains of victims of the 1918 pandemic. It has been proved to be a non-recombinant avian virus ${ }^{11}$.

\section{Sample of population analysed and working method}

The Pyrenees Mountains stretch from the Mediterranean to the Atlantic coast and act as a natural barrier between the two countries of France and Spain. The Basque Country lies on either side of the Pyrenees, its coastline on the Atlantic Ocean. In 1920 the Basque Country had a population of 1272645.

From the parochial and civic records of 21 locations in the Basque provinces of Alava, Biscay and Gipuzkoa, we have recorded the date, age, sex and cause of death for all registered deaths in the years 1918 and 1919. These locations (fig. 1) had at that time a combined population of 129696 inhabitants, i.e. $10.2 \%$ of the total population of the Basque Country. The population sample is very varied and includes urban, industrial and rural locations of differing ecosystems (mountains, wetlands) and altitudes (plateaux, coastal areas), some well situated regarding their proximity to the main routes of communication, linking Paris and Madrid, while others are isolated in the more remote mountain areas.

To draw the graphs and calculate the gross mortality rate per thousand inhabitants per year, we have limited our field of study to the 12-month period in which the pandemic was at its most deadly and in which practically all the deaths due to influenza in the years 1918 and 1919 are concentrated;

4 Guillaume 1978, 168.

5 Darmon 2000, 175.

6 Guedel 1991, 105.

7 Montañà/Pujol 1998, 241-244.

8 Rodríguez Ocaña 1991, 140.

9 Bernabeu 1991.

10 Porras 1997.

11 Taubenberger et al. 2005; Tumpey et al. 2005. 


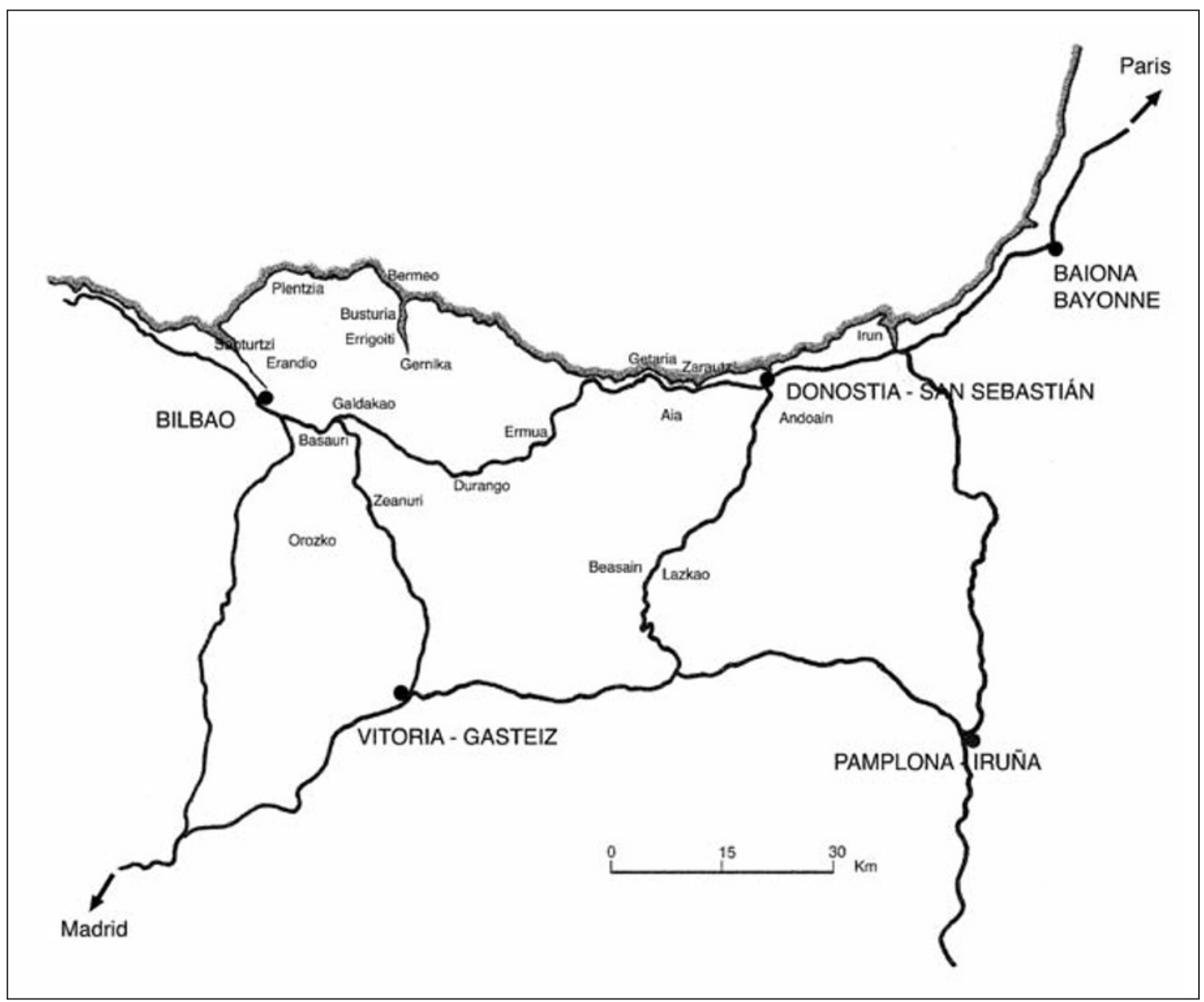

Fig. 1. Locations studied in the Basque Country.

namely from 1st May 1918 to 30th April 1919. We have also differentiated between the entries in the death registers which cite a diagnosis of influenza (grippe, pneumonía grippal, broncopneumonía grippal, enteritis grippal) and those which cite other pathologies of the respiratory tract (pneumonía, broncopneumonía ...) with the exception of pulmonary tuberculosis. Differentiating in this way means that we can arrive at an exact figure for deaths caused by Spanish influenza, a figure which represents the minimum number of fatalities which can be attributed to the virus and, at a second level, the number of deaths caused by direct respiratory complications. The sum of these two figures gives us the maximum death toll for the Spanish influenza pandemic in this part of Europe. These figures are among the most accurate we have and are higher than those suggested by previous studies published in Europe that only take into account official diagnoses of influenza recorded in annual epidemiological reports and in the military archives of those countries caught up in the conflict of the First World War, or arrive at death tolls via mathematical calculations based on an excess mortality. 


\section{The first wave (spring 1918)}

Patterson and Pyle put forward the hypothesis that the first wave of the epidemic reached parts of the French coast, Portugal and southern Spain sometime between the beginning of April and the end of May. In the case of the Iberian Peninsula, Echeverri ${ }^{12}$ points out that it affected the Spanish provinces closest to Portugal and those in the central regions of the peninsula, while hardly affecting the northernmost provinces at all.

Our research confirms that this first wave of the epidemic had very little effect on the Basque Country. Between May and the beginning of July we have found few records of deaths due to influenza in Bilbao, Vitoria-Gasteiz and Pamplona.

\section{The second wave (autumn 1918)}

By the beginning of September the disease was unusually virulent in the border region between France and Spain, with Irun (population 14161), situated at the mouth of the river Bidasoa, being one of the towns most affected.

In the French department of Pyrénées-Atlantiques within the borders of which lies the French Basque Country, Darmon ${ }^{13}$ estimated a mortality rate of 3\% for the period between September 1918 and April 1919. He also estimated a 3\% rate for Bordeaux and the department of Gironde, and rates of $1.7 \%$ for Gers, 7.4 and $1.2 \%$ for the urban centers of Hautes-Pyrénées and the rural areas of Landes respectively. These figures suggest that the impact of Spanish influenza was not so severe on the northern side of the Pyrenees.

To the south of the border, from where this second wave seems to have originated, the death toll for the town of Irun is dramatically high (fig. 2). Death certificates from this area indicate a high mortality rate for diseases of the respiratory system. Diagnoses of influenza do not appear until 10th September. The number of these deaths, which in my opinion are directly linked to the Spanish influenza virus, rose to 75 for diseases of the respiratory tract and 16 for influenza in the month of September and 41 and 7 respectively for the month of October ${ }^{14}$. Influenza and respiratory complications resulting from influenza caused the death of $9.8 \%$ of the population of Irun during these two months and $15.2 \%$ of the population in the total

12 Echeverri 1993.

13 Darmon 2000, 173.

14 Donostiako Elizbarrutiko Artxibo Historikoa. 


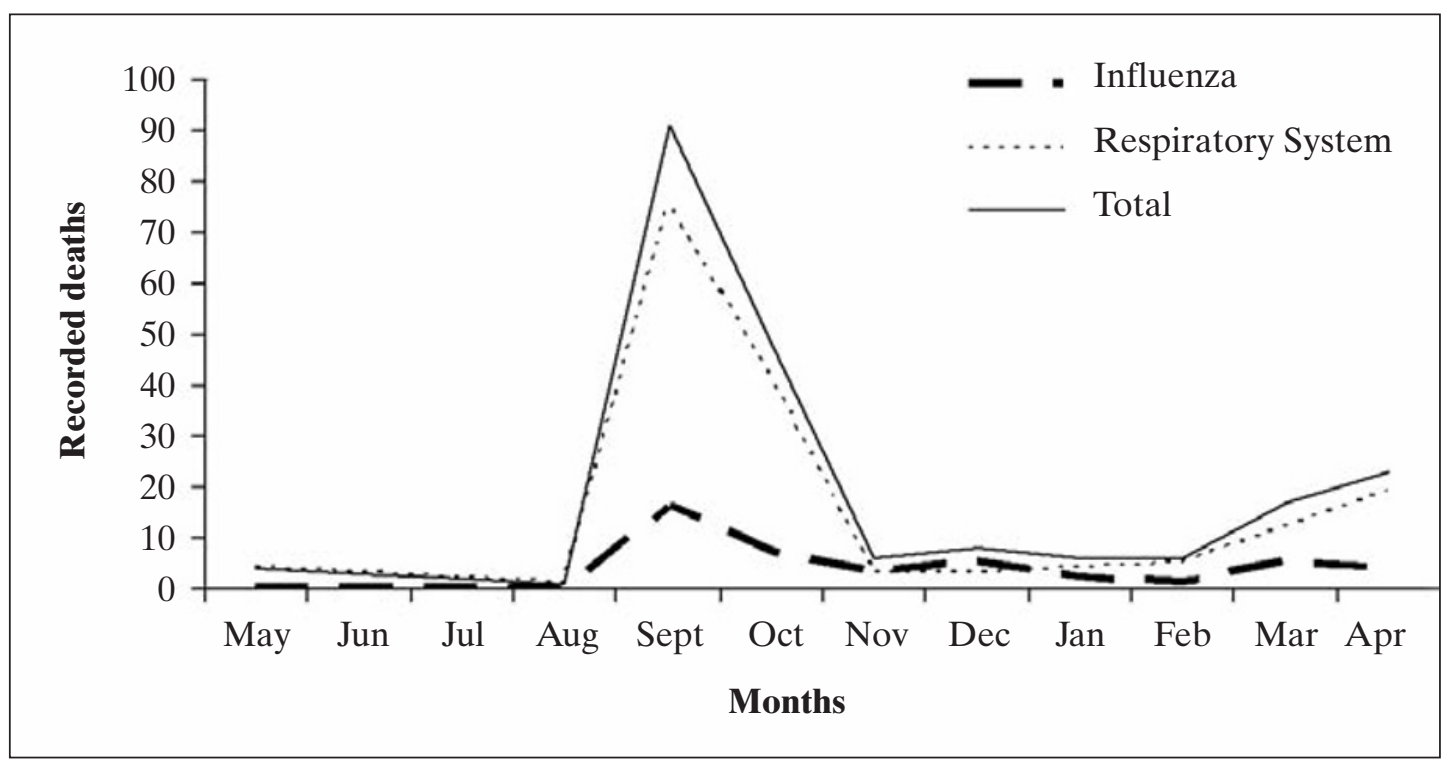

Fig. 2. Irun (May 1918-April 1919).

12-month period studied (the gross mortality rate for all causes of death in this 12 -month period rose to $30.9 \%$ ). The number of male victims of influenza was far higher than the corresponding number of female victims, while almost all victims were adolescents and young adults (the majority being between 15 and 34 years of age).

The pandemic spread rapidly from north to south along the main routes of communication between Paris and Madrid and by October encompassed the rest of the country. In Vitoria-Gasteiz for example (fig. 3), it played havoc with the population towards the end of September and reached its peak of devastation between the 19th and 22nd October. Again it affected mainly young people between the ages of 15 and 34, the majority of the victims being males $^{15}$. In Vitoria during the months of October and November, influenza and its resultant respiratory complications were responsible for a mortality rate of 5.7\% . For the 12-month period studied the rate was $11.3 \%$ o (the gross mortality rate for all causes of death over the same 12-month period was $29.6 \%$ ).

In certain mountain villages the peak of maximum affect did not occur until November (fig. 4) and the mortality rate for deaths from influenza and respiratory complications was the highest found in our research ${ }^{16}$. In Orozko and Zeanuri 25.7 and $24.1 \%$ died respectively (the gross mortality rate for all causes of death in Zeanuri, in the 12-month period studied, reached $52.7 \%$ ).

15 Archivo Municipal de Vitoria-Gasteiz-ko Udal Artxiboa.

16 Bizkaiko Elizaren Histori Arkibua. 


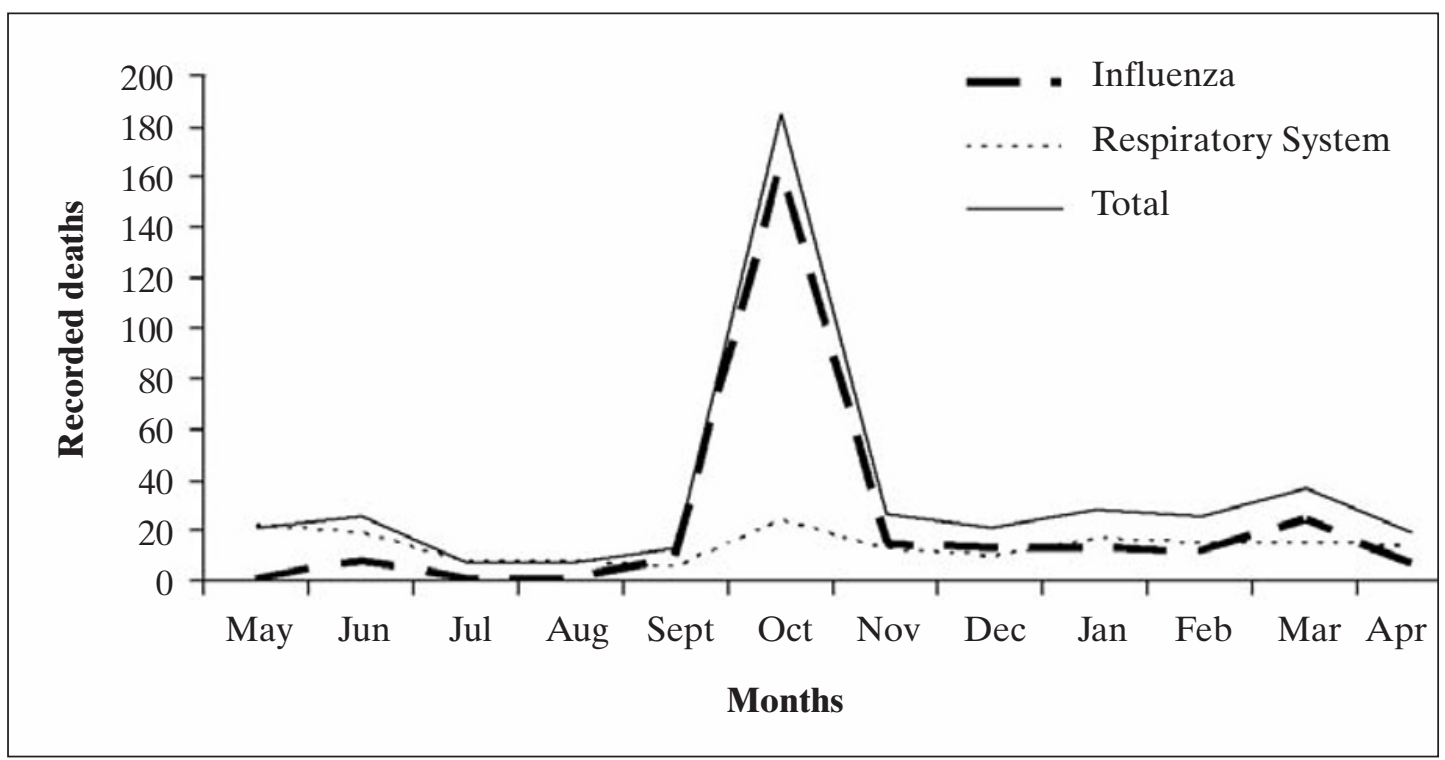

Fig. 3. Vitoria-Gasteiz (May 1918-April 1919).

\section{The third wave}

There was no third wave in the Basque Country, although in certain towns along the Mundaka estuary in what is now the Urdaibai Biosphere Reserve, an area characterised then as now by its being a haven for a great variety of wetland wildlife as well as large numbers of migratory birds, the characteristics of the epidemic were unlike those for the rest of the territory. Here, in Busturia and Gernika, there was no first wave of the epidemic at the end of the spring of 1918 and the second wave, which occurred between September and November, was not as virulent. The epidemic really took off, however, at the beginning of 1919, reaching its peak in February, before easing significantly in the month of March and petering out altogether in April (fig. 5).

\section{A summary of the pandemic in the Basque Country}

As we have seen, despite the relatively small size of the area under study (around $20000 \mathrm{~km}^{2}$ ), significant differences exist between one region and the next. One can deduce that in the Basque Country as a whole, the first and third waves hardly manifested themselves, and the second wave occurred principally in the month of October (fig. 6). In the 12-month period studied, morbidity was somewhere in the region of $55 \%$, while considerable differences were found between locations in terms of the gross mortality rate 


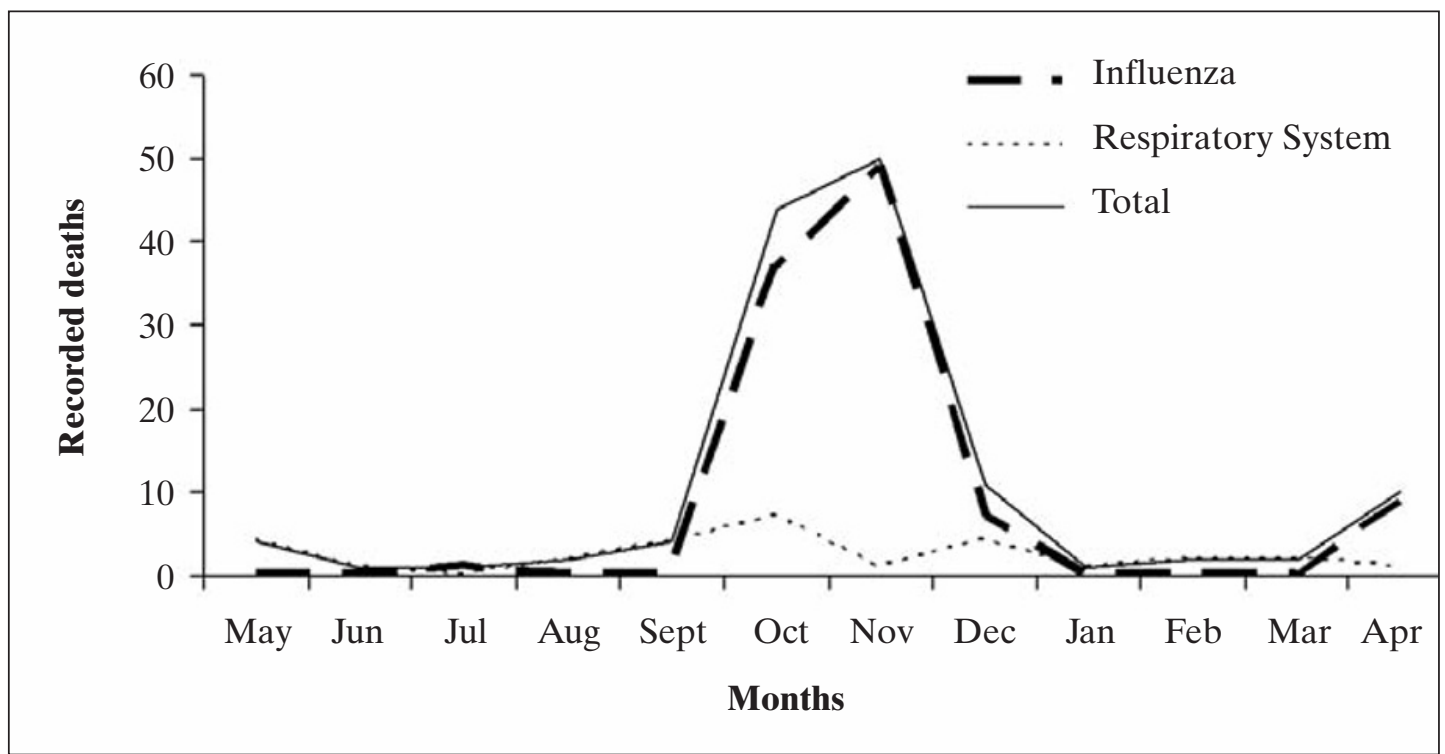

Fig. 4. Orozko and Zeanuri (May 1918-April 1919).

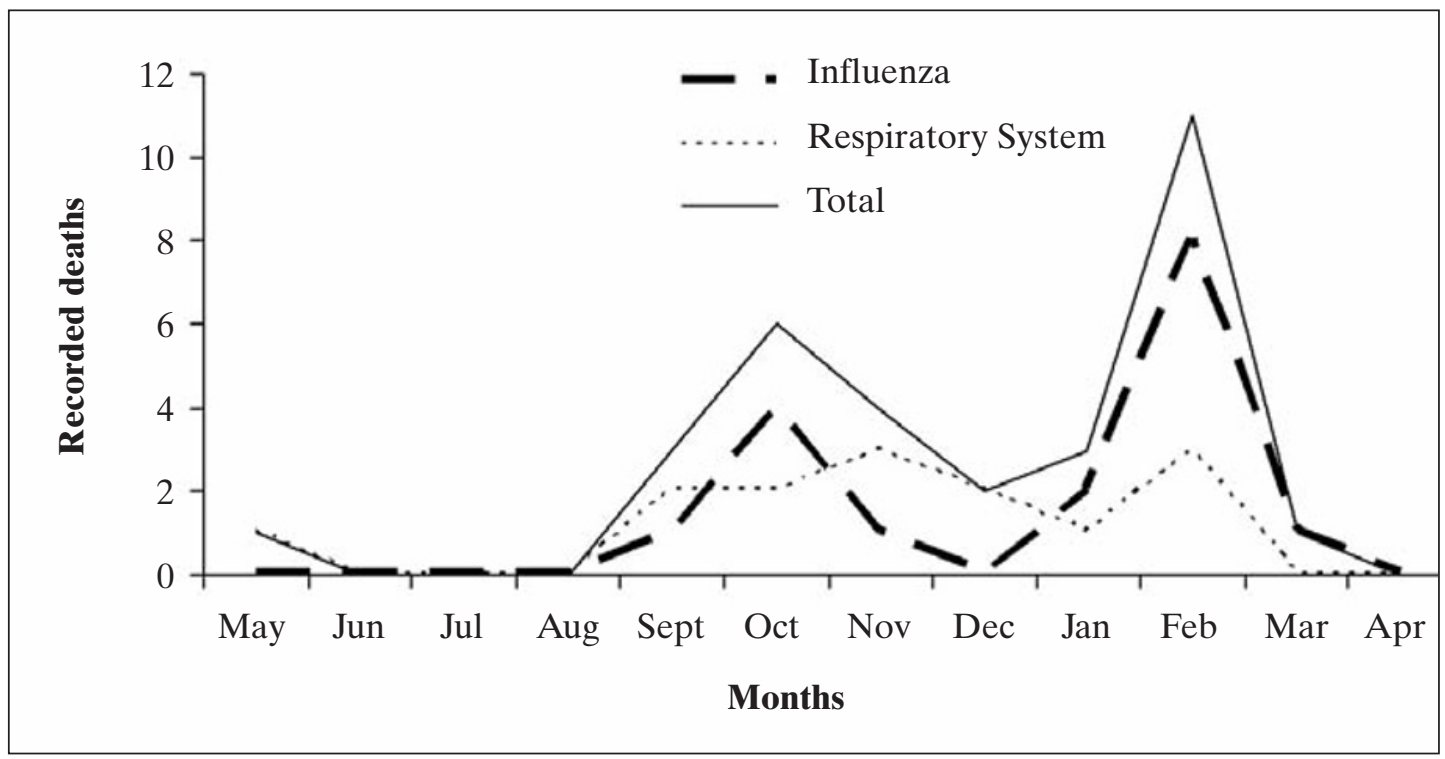

Fig. 5. Busturia and Gernika (May 1918-April 1919).

for deaths caused by influenza and complications of the respiratory system (table 1), the lowest being that for Aia, the highest that for Orozko. To calculate the average for the 21 locations studied ${ }^{17}$, we put the minimum and maximum mortality rates in the Basque Country at $6.8 \%$ or deaths due to influenza and $12.1 \%$ for deaths caused by influenza and diseases of the respiratory system combined.

17 Erkoreka 2006, 34. 


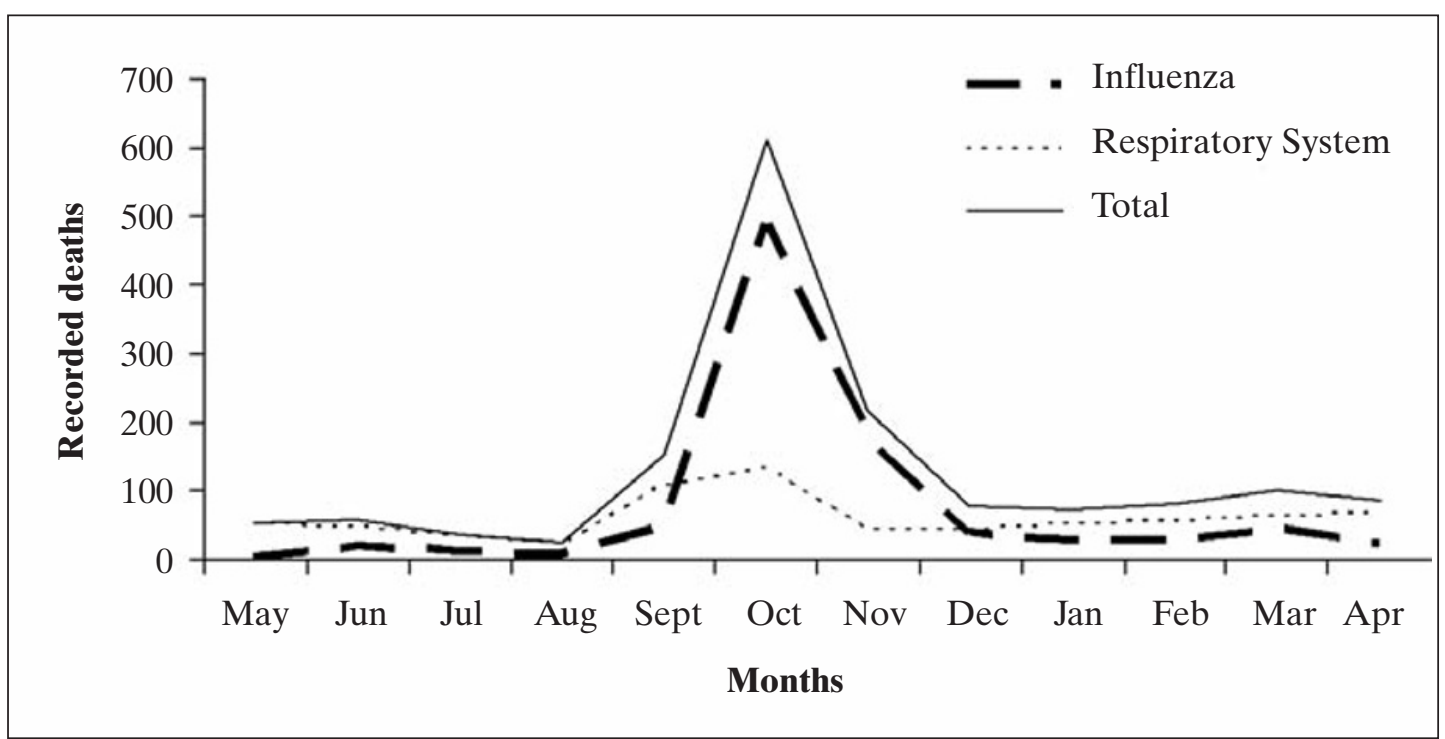

Fig. 6. Basque Country (May 1918-April 1919).

Table 1. The Spanish influenza in the Basque Country (May 1918-April 1919), gross mortality rates per 1000 inhabitants per year.

\begin{tabular}{lcc}
\hline & influenza & influenza + respiratory system \\
\hline Aia & $2.2 \%$ o & $7.5 \%$ \\
\hline Vitoria-Gasteiz & $6.9 \%$ o & $11.3 \%$ \\
\hline Orozko & $19.7 \%$ o & $25.7 \%$ \\
\hline Basque Country & $6.8 \%$ & $\mathbf{1 2 . 1} \%$ \\
\hline
\end{tabular}

In terms of age, the vast majority of deaths were found among the young and those in early adulthood, while regarding the sex, of the victims of influenza, 53.0 were men and $47.0 \%$ women (fig. 7). It is interesting to note that for deaths from respiratory disorders only, the proportion is more balanced: 51.6 men versus $48.4 \%$ women.

\section{Conclusions}

The first wave of the epidemic in the spring of 1918 was a seasonal and benign influenza epidemic such as those that occur almost every year causing a low mortality rate. If there had only been this one epidemic wave, it would not have gone down in history and neither would we be interested in carrying out this research. 


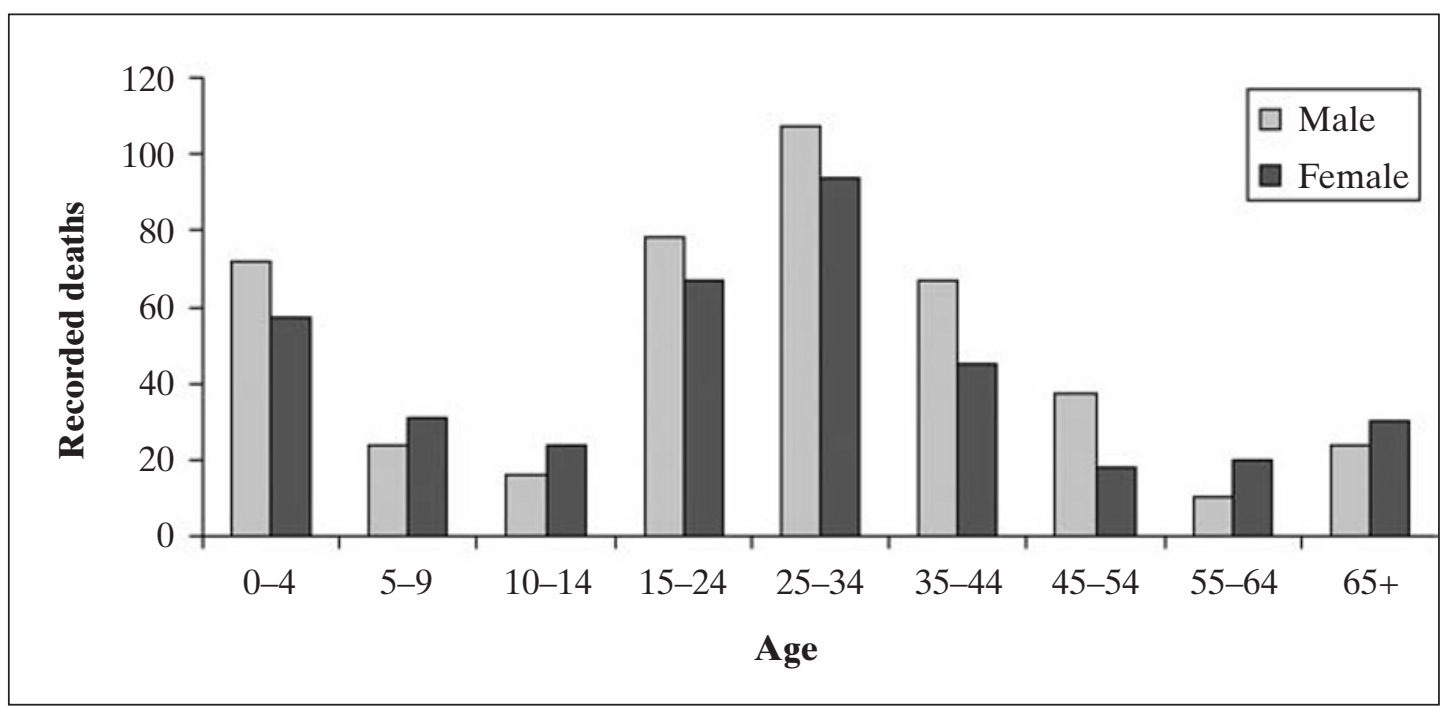

Fig. 7. Basque Country (May 1918-April 1919).

However, in the summer of 1918, the virus mutated in Europe and the epidemic took on pandemic proportions. From the data provided, we believe that one of the places where this mutation occurred was in the frontier region between France and Spain, with the epicentre in the towns of Irun, Hendaia and Hondarribia, towns lying on both sides of the frontier area, at the mouth of the river Bidasoa.

It is quite possible that the mutated virus was a recombinant between the virus carried by the American troops into Europe in the Spring of 1918 and the virus causing "pneumonie des Annamites", present on French soil from 1916 on. The recombination would have been fostered by the terrible circumstances that its French population underwent as a result of the First World War with upheavals of the civil population, troops from all the Continents, hunger, the packing together of human bodies and chemical and biological contamination.

One publication at the time pointed out that the epidemic in the United States broke out on 5th March, among Chinese workers, at the military base at Fort Riley, Funston (Kansas) ${ }^{18}$. In one of the reports I consulted in the Archives du Service de Santé des Armées, the American epidemic was said to have broken out a month before: "M. Carrière affirme que la grippe a commencé en février aux Etats-Unis dans la prison de Sing-Sing, NewYork; de là, par l'armée américaine, elle aurait gagné, en avril, la France, l'Espagne ..."19. Concerning the "pneumonie des Annamites", it arose and

18 Vaughan 1921,70.

19 Le Médecin-Major de I classe A. Pic, Adjoint Technique au Directeur du Service de Santé de la $14^{\circ}$ Région, à M. le Sous-Secrétaire d'Etat du Service de Santé Militaire ... le 15 novembre 1918 (ASSA, carton 813). 
developed, in the main, among the "indigenous" troops of Indochina fighting in the French army.

Throughout the month of September 1918, the mutated virus remained entrenched at the Franco/Spanish border causing enormous death tolls. By October, the pandemic had spread and struck with an unaccustomed virulence in the cities of Bordeaux, Paris, Lyon, Andorra, Barcelona, Alicante and Madrid. Between October and November the pandemic had spread to the Balearic Islands ${ }^{20}$, Switzerland ${ }^{21}$ and Germany ${ }^{22}$. By November, the Spanish influenza pandemic had spread to the Straits of Gibraltar ${ }^{23}$, Algeria ${ }^{24}$, Great Britain $^{25}$, Ireland ${ }^{26}$ and other European countries ${ }^{27}$.

\section{Bibliography}

Åman, Margareta, Spanska Sjukan. Den svenska epidemin 1918-1920 och dess internationella bakgrund (Uppsala 1990)

Ammon, C. E., «L'épidémie de grippe espagnole de 1918 à Genève, Suisse», Euro Surveill 7 (2002) 190-192

Bernabeu, Josep, La ciutat devant el contagi: Alacant $i$ la grip de 1918-19 (Valencia 1991)

Darmon, Pierre, «Une tragédie dans la tragédie: la grippe espagnole en France (avril 1918 - avril 1919)», Annales de démographie historique 2 (2000) 153-175

Dupâquier, Jacques, «Introduction», in: Jean-Pierre Bardet/Jacques Dupâquier (éds), Histoire des populations de l'Europe. II. La révolution démographique 1750-1914 (Paris 1998) 7-17

Echeverri, Beatriz, La gripe española. La pandemia de 1918-1919 (Madrid 1993)

- "Death in winter: Spanish influenza seen from Spain", in: Howard Phillips/David Killingray (eds), The Spanish Influenza Pandemic of 1918-19 (London 2003) 173-190

Erkoreka, Anton, La pandemia de gripe española en el País Vasco (1918-1919) (Bilbao 2006)

Guedel, Nicolas, L'épidémie de grippe «espagnole» de 1918-19 et ses répercussions dans la ville de Lyon (Lyon 1991)

Guillaume, Pierre, «La grippe à Bordeaux en 1918», Annales de démographie historique (1978) 167-173

Herrera, Francisco/José Almenara, «La epidemia de gripe de 1918 en San Fernando (Cadiz)», An. R. Acad. Med. Cir. Cadiz 30 (1994) 131-187

Johnson, N. P. A. S., "The overshadowed killer. Influenza in Britain in 1918-19", in: Howard Phillips/David Killingray (eds), The Spanish Influenza Pandemic of 1918-19 (London 2003) 132-155

- Juergen Mueller, "Updating the accounts: global mortality of the 1918-1920 'Spanish' influenza pandemic", Bulletin of the History of Medicine 76 (2002) 105-115

Lluch i Dubon, Ferran Dídac, L'epidemia de grip de l'any 1918 a les Illes Balears (Mallorca 1991)

20 Lluch i Dubon 1991.

21 Ammon 2002.

22 Le Médecin-Major ... op. cit.: "L'épidémie, en effet, a existé dans les camps de concentration allemands avant d'exister en Suisse; elle a été observée dans les troupes combattantes allemandes, avant de l'être parmi les groupes suisses» (ASSA, carton 813).

23 Herrera/Almenara 1994.

24 Rapport du Médecin Major de CL. L. Raynaud adjoint technique de la $19^{\circ}$ Région au sujet de la grippe (ASSA, carton 814).

25 Johnson 2003, 134.

26 Thompson 1920.

27 Phillips/Killingray 2003, Åman 1990. 
Montañà, D./J. Pujol, «L'epidèmia de grip del 1918 al Principat d'Andorra», Gimbernat 30 (1998) 237-245

Patterson, K. David/Gerald F. Pyle, "The geography and mortality of the 1918 influenza pandemic", Bulletin of the History of Medicine 65 (1991) 4-21

Phillips, Howard/David Killingray (eds), The Spanish Influenza Pandemic of 1918-19 (London 2003)

Porras, María Isabel, Un reto para la sociedad madrileña: la epidemia de gripe de 1918-19 (Madrid 1997)

Rodríguez Ocaña, E., «La grip a Barcelona: un greu problema esporàdic de salut pública», in: Cent anys de salut pública a Barcelona (Barcelona 1991) 131-156

Taubenberger, Jeffery K. et al., "Characterization of the 1918 Influenza Virus Polymerase Genes", Nature 437 (2005) 889-893

Thompson, W. J., "Mortality from influenza in Ireland", Dublin Journal of Medical Science (1920) 174-186

Tumpey, Terrence M. et al. "Characterization of the reconstructed 1918 Spanish influenza pandemic virus", Science 310 (2005) 77-80

Vaughan, W. T., Influenza: An Epidemiologic Study (Baltimore 1921)

Zylberman, Patrick, "A holocaust in a holocaust. The Great War and the 1918 Spanish influenza epidemic in France", in: Howard Phillips/David Killingray (eds), The Spanish Influenza Pandemic of 1918-19 (London 2003) 91-201 